\title{
Sustainable drainage systems: helping people live with water
}

\section{Glyn Everett $\mathrm{PhD}$}

Research Fellow, Centre for Floods, Communities and Resilience, University of the West of England, Bristol, UK

2 Jessica Lamond $P h D$

Associate Professor, Centre for Floods, Communities and Resilience, University of the West of England, Bristol, UK

3 Anita T. Morzillo PhD

Assistant Professor, Department of Natural Resources and the Environment, University of Connecticut, USA
4 Faith Ka Shun Chan PhD

Assistant Professor of Geographical Sciences, Environmental Sciences, Department of Geographical Science, University of Nottingham, Ningbo Campus, People's Republic of China

5 Annie Marissa Matsler MEM

Graduate Student, Toulan School of Urban Studies and Planning, Portland State University, USA
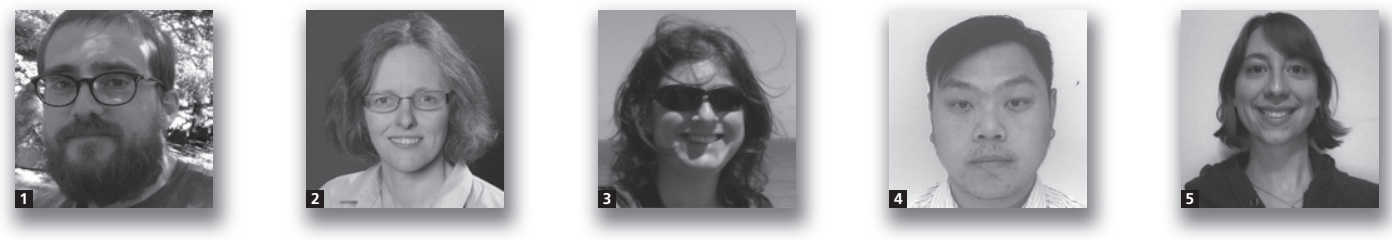

Sustainable drainage systems or 'Suds' are increasingly accepted as an effective means of 'making space for water', adapting to possible climate change and helping communities become more flood and drought resilient. This study explores potential shifts in perception and attitude through Suds installation, development and habituation. Attitudes and awareness in communities in the USA and UK, where Suds have been in place for some time, were compared and contrasted, examining any evolution of beliefs and practices and wider community resilience. The principal finding was that there existed a lack of understanding about the existence and function of Suds. The paper concludes that consultation regarding solutions during Suds planning and installation, and ongoing dialogue afterwards, could usefully be explored as a means to improve local awareness of and satisfaction with Suds and promote greater understanding of their function. This may in turn encourage behaviour change to improve longer-term functionality of Suds and increase community resilience to flooding and drought.

\section{Introduction}

Policies in the USA and the UK now favour more 'sustainable' approaches to flood risk management (EPA, 2007, 2013; Defra, 2005; Pitt, 2008; Scottish Government, 2003; Werritty et al., 2007). Sustainable drainage systems (Suds), known as 'best management practices' (BMPs) and 'low-impact development' (Lid) in the USA, are surface water drainage systems designed to function in a manner akin to natural drainage. Positive impacts include delivering a sequence of sustainable water management practices, such as reducing surface water runoff, improving water quality and enhancing amenity and biodiversity functions. Suds have been described as 'a catch-all term for a number of different systems' (Jones and MacDonald, 2007) for slowing, filtering or retaining runoff, and putting excess water to use near where it lands rather than dispersing it quickly. Suds can be anything from water butts (rain barrels) and permeable paving, to green roofs, wetlands, ponds, filter and infiltration trenches, swales and rain gardens. Since over $80 \%$ of the populations in the USA and the UK live in already developed urban areas (World Bank, 2014), the focus for this research is specifically upon retrofit Suds in the urban environment.

Many urban Suds systems are now well established; evaluation of longer-term performance is possible - and emerging (Davis et al., 2001; Mitchell, 2005). For example, research has explored the deterioration in infiltration at parking sites (Achleitner et al., 2007), identification of the best performing vegetation in rain gardens (Land and Water Constructions, 2006), maintenance regimes for Suds ponds in Scotland (Heal, 2000) and England (Heal et al., 2008), eco-roof performance in the USA (Kurtz, 2010) and green roof storage capacity (Getter et al., 2007). Some research has also been carried out to determine the social benefits of Suds as implicitly measured through house prices over time (Netusil et al., 2014; Zhou et al., 2013).

What is less well understood is how Suds are perceived by their local communities (although some research is emerging, see Shandas et al. (2010)). This should be a central concern, 
because such perceptions will affect the 'felt' benefits and costs of Suds, willingness to contribute towards maintenance costs and how people interact with them and, therefore, will have an impact on how 'sustainable' they are likely to be (the life expectancy of installations). The opinions of professional bodies and authorities will of course be central to whether and how Suds are implemented, but the research in this paper focuses on the much less studied matter of interactions between Suds and local communities.

The small number of studies conducted around public perceptions and attitudes towards Suds have produced contrasting results. Werritty et al. (2007) found that respondents preferred structural flood defences (e.g. concrete walls or levees), these being supported by over $90 \%$ of respondents, with Suds low down the list. Johnson and Priest (2008) found that the insurance industry, media and public remain 'heavily focused' on using structural defences. In contrast, Wendy Kenyon (2007) found that flood walls and embankments were respondents' least favoured options; instead approaches such as regenerating or planting native woodlands were preferred. Similarly overall, Apostolaki and Jefferies (2005) found that respondents preferred 'softer' approaches to managing flood risk, such that attitudes toward ponds and managed rivers were found to be positive because of their amenity, recreation, biodiversity and aesthetic benefits. Awareness of Suds' flood functions, however, was low, with most respondents unaware of their contribution to controlling, filtering and slowing runoff (Apostolaki and Jefferies, 2005).

In the study by Apostolaki and Jefferies (2005), views about Suds were found to be related to awareness of the functions and services they provided: flood control, improved water quality, opportunities for water harvesting and improved amenities, recreation facilities and biodiversity. One of their overriding findings and messages, therefore, was that education and consultation are fundamental to building understanding to enable sustainable strategies to be more effectively pursued, appreciated, managed and maintained. More recently, work by Bastien et al. (2011) found public awareness of the Suds functions of ponds to be much higher than was found by Apostolaki and Jefferies (2005), with close to $75 \%$ of people surveyed understanding their contribution to reducing flood risk. They nonetheless again emphasised the value of educational work around Suds ponds; safety, for example, was the most significant public concern around ponds, yet large differences existed between perceived and actual safety levels (see also McKissock et al., 1999).

The disparity between findings in these studies points to the need to establish a more thorough understanding around public perceptions of different Suds approaches. This research addresses the disparity by comparing residents' views and understandings of facilities between two sites: one in the USA and one in the UK. The purpose of these two small, in-depth, qualitative studies was not to produce widely generalisable findings, but rather to help deepen understanding of how people perceive the purpose and functioning of specific urban Suds designed to control surface water flow at source, behaviours around these Suds, and whether this behaviour is likely to facilitate or impede functioning.

\section{Methods}

This study focused on one site in the USA and one in the UK (see Figure 1) where Suds have been part of the landscape for the past $8-10$ years. This was on the basis that the installations would no longer be seen as 'new' and that any behaviour changes they might encourage from those living in proximity would have occurred. In other words, the devices would be viewed as more natural or 'normal' (Barr et al., 2011; Hargreaves, 2010; Proshansy et al., 1983). The sites were located in the two climatically comparable locales of Bristol (UK) and Portland (Oregon, USA). In Bristol the Suds of interest were permeable paving (and a restored park area), and in Portland they were bioswales; both were installed in 2005-2006.

In Bristol, the area was the recipient of a government improvement grant in 2004, which included the installation of permeable paving (see Figure 2). It is close to the city centre and almost entirely residential. The area has an active residents' association and won an award several years ago for the strength of its community activities. Shortly before the permeable paving was installed, the association won another grant to restore a large rubbled area to structured parkland, further increasing water absorbency capacity.

Portland's Bureau of Environmental Services (BES) has been developing sustainable stormwater management facilities since the early 1990s (Reinhardt, 2011). In 1999, the city's stormwater management manual (SWMM) was officially adopted

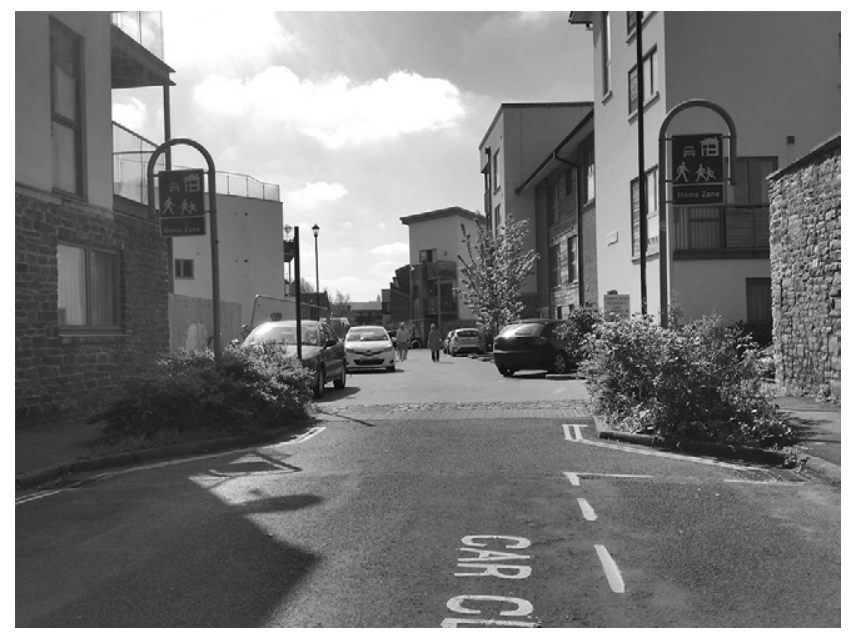

Figure 1. Site in the UK 
Sustainable drainage systems: helping people live with water

Everett, Lamond, Morzillo, Chan and Matsler

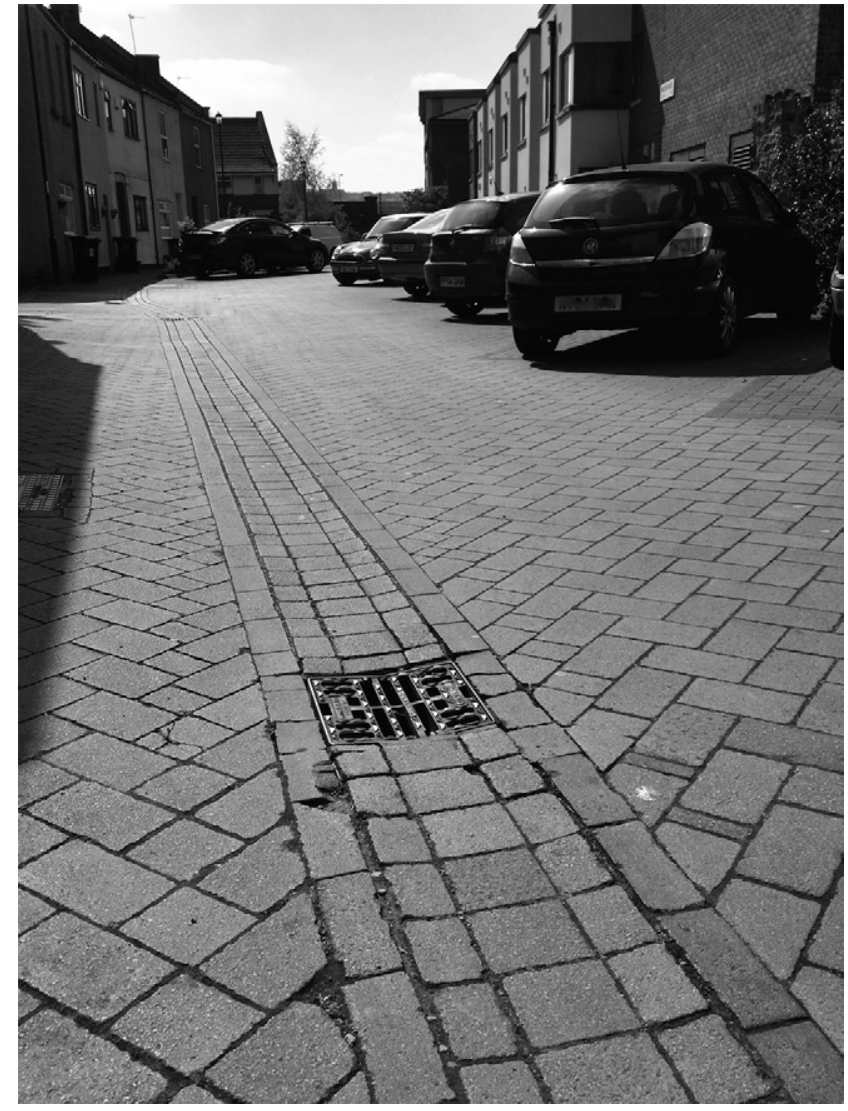

Figure 2. Permeable paving in the UK

(BES, 2005), and a city-wide 'Green Streets' programme was initiated in 2005 (BES, 2007). The stormwater management and 'Green Streets' programmes focus on reducing street flooding and filtering rainfall before it reaches the Willamette and Columbia Rivers, which run through the centre and north boundary of the city. The current programme requires all street improvements to accommodate stormwater management techniques. Part of this programme involves installing bioswales within, or as extensions to, pavements (see Figures 3 and 4) (BES, 2014). In Portland, the study site was located 5 miles $(8.05 \mathrm{~km})$ from the city centre along a main street; bioswales were installed when the road was tarmacked and pavements installed.

A semi-structured interview approach (Wengraf, 2001) was adopted to allow respondents to talk freely around 12 key questions, with the interviewer to follow up on main points of interest. Interviews were designed to last $35-45 \mathrm{~min}$. Respondents were informed of the nature and purpose of the research, asked to provide consent acknowledging that anonymised quotes may be used, and assured they could withdraw consent at any time. The Portland State University Office of Research Integrity and University of the West of England Faculty Research Ethics Committee provided approval for use

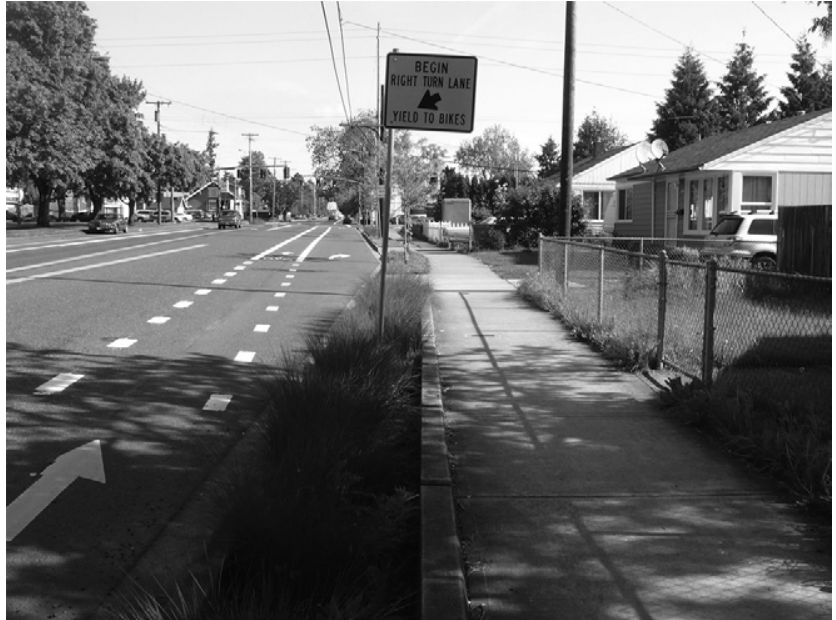

Figure 3. Bioswale in the USA

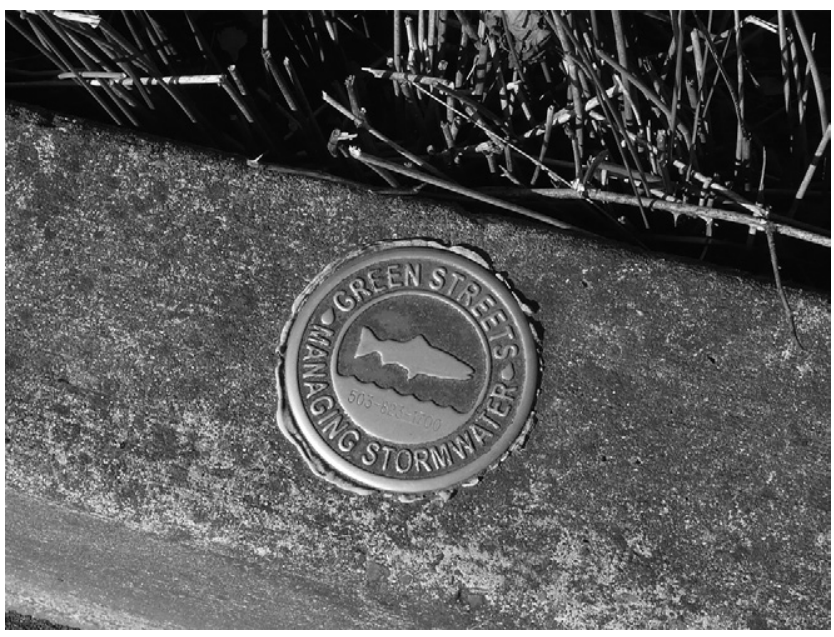

Figure 4. 'Green Streets' logo, USA

of human subjects in the USA and the UK, respectively (IRB\#143039 and FETREC 1314-15).

Potential respondents were initially contacted by attending a residents' association meeting in the UK, and by distributing A5 flyers to households in Portland. In Portland, response to flyers was very poor, and so the researchers adopted an alternative approach and spoke with people outside their houses. These point-of-opportunity interactions tended to be somewhat shorter, but still achieved a mean average of $26 \mathrm{~min}$ and proved equally fruitful in terms of the quality and range of data gathered.

Nine individuals were interviewed at each site. Responses were transcribed and analysed using qualitative data analysis software (NVivo). A grounded theory approach was used whereby 
theory is developed into themes from data collected, presuming as little as possible beforehand (Bryant and Charmaz, 2010; Glaser and Strauss, 2009). The purpose of this research was to investigate individual perceptions and behaviour in depth, illuminating important issues that might carry over to other sites and situations.

\section{Findings}

\subsection{Awareness and understanding}

Across both sites results supported the work of Apostolaki and Jefferies (2005) and Bastien et al. (2011): awareness of the existence, and/or purpose and function of Suds tended to be quite limited. A clear lack of awareness that any drainage system had been put in place was in evidence in Bristol, as one respondent commented

When you came to our [residents'] meeting ... I think it was only me and who had any idea what you were talking about! (respondent no. 11.01.05.2)

People were aware the road surface looked different to other roads (see Figure 5), but often had no further insight as to its purpose. Responses suggested the presumed function was to distinguish the area from surrounding streets.

The really brilliant thing about it is that if you are driving down the road, you think 'oh, can I go in there?' ... It totally discourages people from driving through the neighbourhood. (respondent no. 11.01.04.2)

A respondent who was new to the neighbourhood said

I am [aware] now! Only since we were told about it. I mean, until the residents meeting ... I wouldn't be surprised if a lot of the people who lived here when it was put in didn't actually realise it served a drainage purpose. (respondent no. 11.01.04.1)

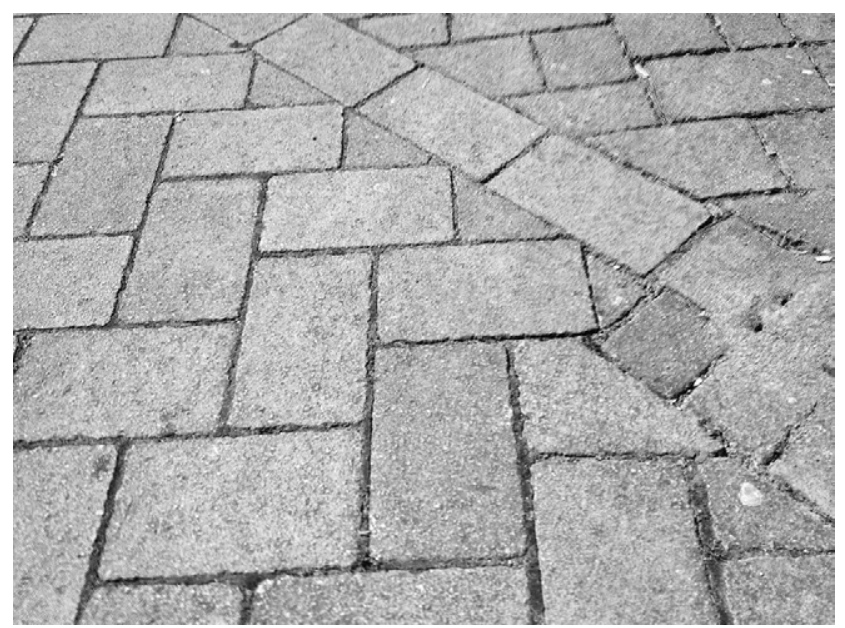

Figure 5. Permeable paving in the UK - close-up
Similarly, a longer-term homeowner responded

I see that these streets, they look different to other kinds of streets, but before you came to ask us, I didn't really take any notice of the draining system ... what does it, it's the water, is that right? (respondent no. 11.01.02.2)

As respondent 11.01.05.2 above notes, those who were involved in negotiating the street improvements tended to be more aware.

I do know about the Suds because it came in when I was here ... we were consulted on what went in ... So I'm aware that we haven't got flooded when everyone else got flooded. (respondent no. 11.01.05.2)

However, a resident who had been around since before the changes but not involved with the residents' association was unaware.

I thought it was mainly just to be flat for people, for wheelchairs, pushchairs - making it safer. (respondent no. 11.01.01.2)

Responses suggest that, unless people had been involved from the beginning or spoken with someone who had, they were likely to be unaware the road was permeable. They would be aware the streets looked different, but not about design function.

In Portland, the bioswales are a more obvious intervention, large visible entities taking up part of the pavement, or acting as an extension to the pavement (see Figures 6 and 7). Awareness of their existence was consequently much higher than in the UK study. Awareness of function was correspondingly somewhat higher, but still not good. For example, two respondents were unaware of their role in water management.

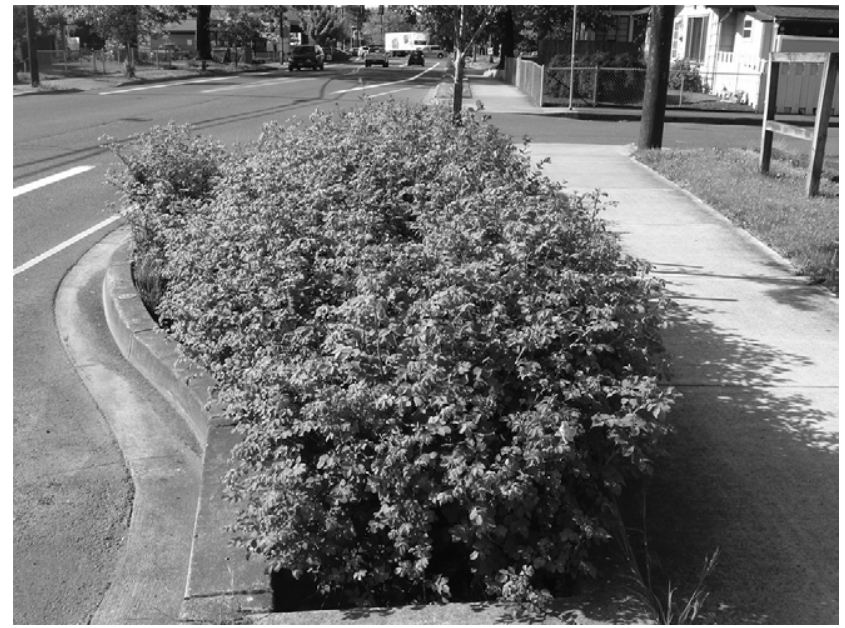

Figure 6. Bioswale with kerb-cut in the USA 


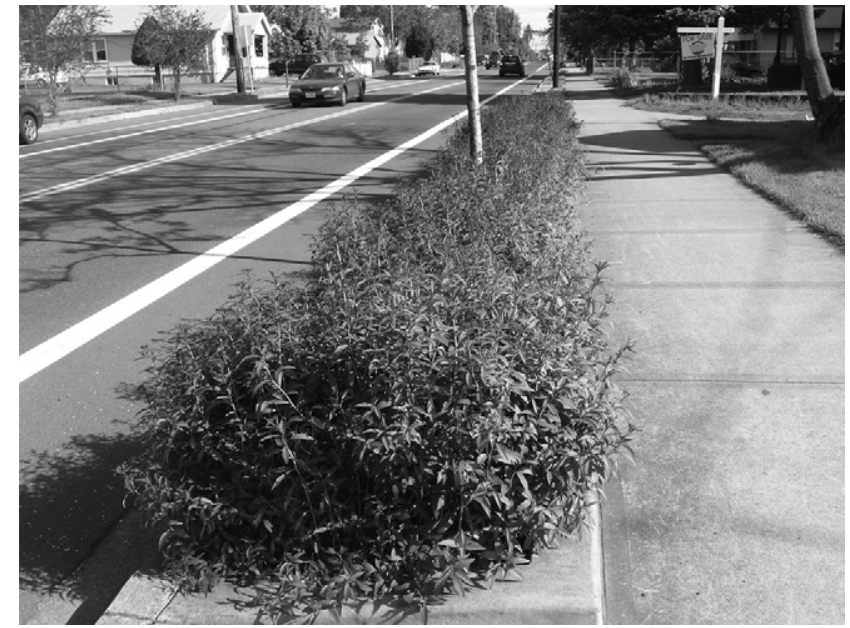

Figure 7. Bioswale without kerb-cut in the USA

Interviewer: Do you know much about their role in water...?

I don't know much about that. That explains why it's so deep then! I didn't know that's what they were for ... I bet you, a lot of us don't know it's for the water.' (respondent no. 01.01.02.2)

You educated me - I didn't know it's for the water. I just thought it's pretty, and it looks nice for the neighbourhood. (respondent no. 01.01.03.2)

Other respondents were aware of their advertised role in cleaning the water system, but either misunderstood how this worked or did not believe it could function.

I'm not exactly sure what does what, but ... I know it's supposed to clean up the water before it gets to the sewer-drain or whatever. (respondent no. 01.01.07.1)

The bioswales were installed to reduce the amount of stormwater both backing up on the streets, and infiltrating the city's combined sewer system (reducing overflows of untreated sanitary sewage and stormwater into watercourses and greatly improving water quality) (see Figure 8). They also filter pollutants out of stormwater flows (Dingman, 2008; Peters, 1994), further improving water quality downstream. Some respondents were aware of this, with caveats.

They're supposed to keep some of the rainwater from going into the sewage, so far as I know. (respondent no. 01.01.05.1)

Interviewer: And filtering the water before it gets back to the river?

Well, it's got a long way to go before it gets to the river - be a thousand years before it gets there, probably. (respondent no. 01.01.01.1)

They do filter, the water goes in there - although it's all going into one little spot - so it's just like a septic tank (laughs) ... It's all

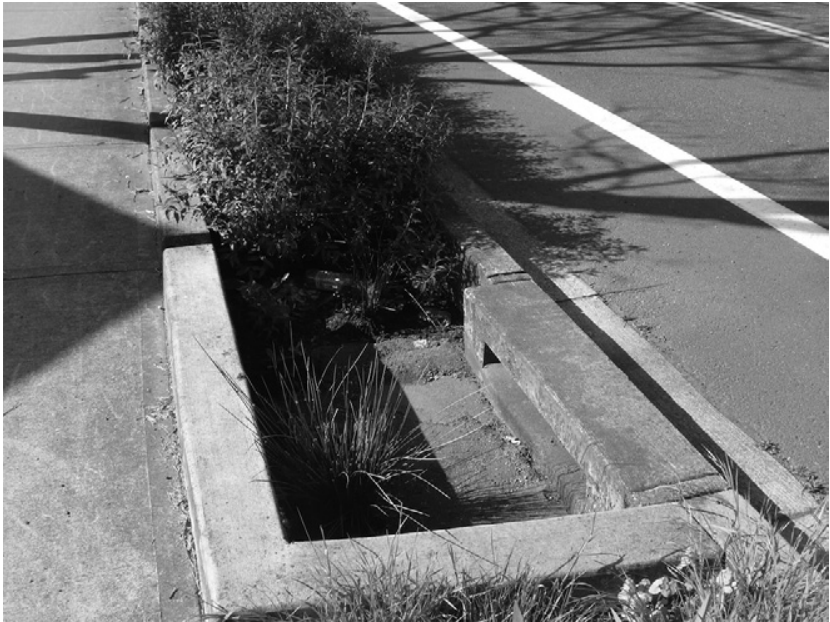

Figure 8. Bioswale inlets in the USA

coming off the roads and going into there - and eventually, since it's all going into one little spot, it's going to develop a concentration of pollutants ... It's real easy to think this is a good thing - but you've got to have some common sense. (respondent no. 01.01.04·1)

Some others, whether or not they understood and accepted the bioswales' function in filtering stormwater, expressed concerns about the ability of the structures to reduce street and basement flooding.

When it's raining hard the $\mathrm{s}^{* *}$ t's gonna run everywhere. Ain't there a little lip before them? So it's gotta flood that high before it goes in? ... A three-quarter inch lip that the water has to go over, and then there's a little gap that clogs up with leaves?' (respondent no. 01.01.01.1)

They don't really address flooding, they address the way that the stormwater enters the system, not flooding. (respondent no. 01.01.06.2)

Weak awareness of purpose and function may affect satisfaction with systems put in place, as well as awareness of appropriate behaviour that could affect functioning.

\subsection{Understanding and behaviour}

The functioning of the Suds systems will be affected by behaviour around them: littering could inhibit water flows, while changes to Suds' vegetation could impact water-cleaning functions. From the authors' interactions, it seemed that some people did not understand how behaviour could affect functioning. First, in Bristol, residents the authors spoke to were surprised to learn about oil's potential effects (oil spillage could impact permeability).

People don't really take care of it because they don't really know ... if oil drops on it, you just think 'oh, never mind,' instead of 
thinking 'oh, we've got to do something about this' ... in terms of behaviour, maybe tenants could be informed a bit more. (respondent no. 11.01.02.2)

Weeds were another behaviour issue. Almost 10 years' postinstallation, weeds were appearing in soil deposits that had become embedded between the bricks. Best practice would be to carefully scoop out the soil and weeds, but people were unaware of this due to a lack of maintenance information.

Interviewer: Do you know anything at all about maintenance that might be needed to help it keep working?

I don't really, no. I suppose, if weeds grow up ... is it meant to maintained? (respondent no. 11.01.02.2)

One resident referred to filling the loose permeable grit between the bricks with cement because he thought he had observed a similar action during installation.

When they put the [permeable] brick pavers down, what they put it in was some kind of sand/cement thing in between it to stop the weeds growing up and, certainly, I put sand and cement in there to stop the weeds growing through. (respondent no. 11.01.03.2)

In Portland, awareness of how litter might impede bioswale functioning was similarly quite low.

Have to be a lot of litter to clog it up. Someone would have to drop their garbage can in there once a week for a month. (respondent no. 01.01.01.1)

One of my elderly neighbours, who was a gardener, he would throw garbage into his swale; he just didn't understand its purpose. (respondent no. 01.01.06.2)

Other behaviours seemed well intentioned, but would again impact functioning.

Somebody, about a year ago, had these little bean-bag, berries in the intake and it was blocking it - somebody was trying to deliver water from them... (respondent no. 01.01.09.2)

Somebody in this one right here, didn't they pull some parts up outof it? They exchanged the plants, they'd choose the plants especially to do what it's not supposed to do. (respondent no. 01.01.06.2)

Thus, the importance of people's understanding of Suds and potential behavioural impacts will help ensure continued functionality as regards flood risk management and water quality treatment.

\subsection{Visual appreciation}

In Bristol, most residents appreciated the permeable paving simply for its contrasting look to tarmac, suggesting a more 'private' zone, as noted above.
Aesthetically it looks very pleasing, much more pleasing to the eye than a normal street ... just the way the bricks have been laid out is quite neat and tidy. (respondent no.

11.01.02.2)

It looks nice ... there are sections where there aren't any kerbs. It does just feel like you're having a stroll through your neighbourhood ... rather than by a semi-industrial estate. (respondent no. 11.01.04.2)

Many respondents in Portland also valued the aesthetics of the bioswales.

It beautifies and it looks much better than it did before ... It's aesthetically pleasing to see it. (respondent no. 01.01.05.2) People, generally, they are really happy that it looks better. (respondent no. 01.01.08.2)

Appreciation of this function was, however, by no means universal

Nah, it's not more green ... I think it's pretty green around here, it looks good to me. I wouldn't live here if it didn't look this green! (respondent no. 01.01.04.1)

Therefore, the aesthetic contributions of Suds might be valued differently based on individual perceptions of specific neighbourhood characteristics.

\subsection{Voice and consultation}

There was general support in Bristol for suggestions of future efforts to inform people about the paving and its required maintenance.

In terms of doing something about it, I don't know, if like when people move in someone could inform them. (respondent no. 11.01.02.2)

The community group would definitely get involved in maintaining it - if I knew how to fix it, outside my front door, I would.

Interviewer: Could leaflets to inform be useful?

Of course it would - I don't see how it could be a disbenefit ... I wish I'd known about it sooner, and I wish I knew more. (respondent no. 11.01.04.1)

Some Portland citizens who were more aware of bioswale functions also expressed concern that the city did not do enough to educate others about their structure and function.

I don't ever remember being told this is what we were getting, or why we were getting it or what its big function was ... They should have had some signs up on the street: 'This is a bioswale and this is what a bioswale does'. But I'm sure there's people who still don't know why they are doing that ... I 
haven't seen any signage anywhere. (respondent no.

01.01.05.2)

The aspect of the bioswales that could have been done better is the education. When they put them in they didn't tell us anything about them ... Now I understand there is the Green Street Stewards programme, where people adopt a bioswale to keep it in good condition. But this didn't come in at the beginning, when there might have been more interest. (respondent no. 01.01.08.2)

Others said they had never received any correspondence or invites to negotiation over installation.

Interviewer: When they were putting them in, did they ever come and tell you what they were doing?

Not me personally, no.

Interviewer: And do you now know much about how they work?

Well no. (respondent no. 01.01.07.2)

They didn't tell us. We didn't get to choose them either, they just put them in. (respondent no. 01.01.02.2)

Informing and educating is a two-way process: Suds designers will need to learn what people want or can cope with and help maintain (or at least not adversely affect) if installations are going to be sustainable and viewed as a positive contribution to stormwater management. Consultation upon solutions, and then on-going dialogue to ensure a continued sense of involvement and ownership, might improve engagement, adoption and so sustainability.

The trees placed in certain bioswales in Portland demonstrate this well.

They look nice, they make the neighbourhood look nice ... I think they're good - and the trees too, they look nice. (respondent no. 01.01.02.2)

They're nice, 'cos they've got the little trees coming out of them, and the little bushes, yeah, they're nice ... they're just beautiful. (respondent no. 01.01.03.2)

Opinions were not consistent, however, for reasons of shading or increased maintenance.

These trees ... I told them I was going to put battery acid on them, because they're blocking my trees ... my trees are going to die for their tree. (respondent no. 01.01.04.1)

That they planted out there? I got to maintain it, but I didn't get to choose to have it and I didn't get to choose what it is ... they never asked me. I don't do a lot to it, but I can't go and cut it down like I'd like to. (respondent no. 01.01.07.1)

Since trees were not placed in every bioswale, pre-installation community engagement could have helped to overcome this

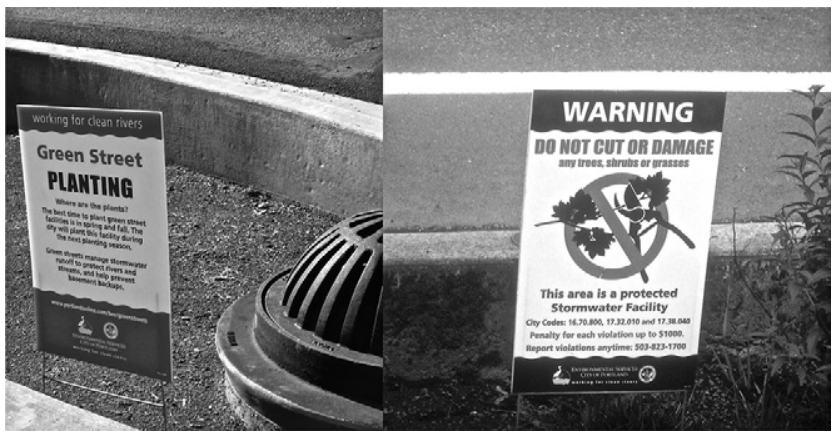

Figure 9. The standard information notices placed in bioswales

inconsistency of opinion (see Figure 9). A sense that services were being tailored to needs and desires could encourage engagement and appreciation.

\subsection{Opinions changing}

The process of installations coming to seem more 'normal' and accepted over time would not appear to hold from the interview samples. Those who understood their purpose tended to be initially supportive, and this did not wane in Portland or Bristol.

I like it! I've always liked it. No, I think it stayed pretty much the same. (respondent no. 11.01.03.2)

I like them just as much today as when I first heard about them ...

I've always just been thoroughly excited about them. (respondent no. 01.01.06.2)

However, interventions or changes since installation could shift attitudes in both directions. For some, appreciation was increased by learning about water-functions.

\footnotetext{
Well now I learnt what they're for, I think they're even better than I did! I really liked it when I moved in ... And now I know it actually serves a purpose, it's even better! (respondent no. 11.01.04.1)

When they first came, I didn't have any idea what they were about! ... you saw them coming up all over town, big ditches on the street. But now, just through our grant, I've learned ... So yes, just from being educated. (respondent no. 01.01.05.2)
}

Whereas for others, in Bristol, opinions about installations worsened over time for some, due to poor behaviour. The paving on one street was lifted 6 months after installation for utilities work (water or gas pipes) and not correctly replaced, creating puddling that a number of respondents commented upon (see Figure 10).

I thought it was good when it first went down ... and it's gone down a bit, because like I say, the mess on ___ Street. It's like most things - it looks good on paper, but you got to live and experience it. (respondent no. 11.01.02.2) 


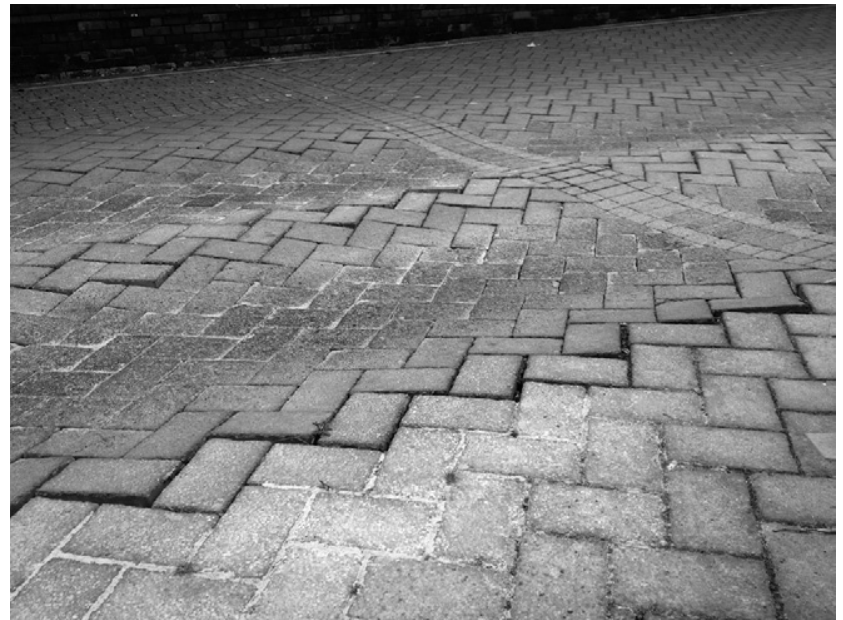

Figure 10. Sunk paving at UK site

When it was first installed ... it was beautiful. Pristine, no litter, no chewing gum, hardly any cars ... Now, it just feels a bit neglected and lost. (respondent no. 11.01.05.2)

\subsection{Maintenance}

Maintenance is an important issue because beyond behaving appropriately, both the Suds and their responsible local authorities could benefit greatly if local residents were engaged to help with minor maintenance tasks. With both permeable paving and bioswales, weeding and cleaning or removing litter would help functioning. However, many people did not support their involvement with this.

It's the council's responsibility, let them $\mathrm{c}^{* *} \mathrm{k}$ it up themselves. (respondent no. 11.01.04.1)

\section{Interviewer: Would you want one in front of you?}

If I'm responsible for the maintenance of it? $\mathrm{H}^{* *} 1$ no, I wouldn't want that. (respondent no. 01.01.01.1)

Importantly, however, a smaller group of respondents expressed a willingness to get involved.

Interviewer: Would you be happy to be involved with maintenance?

Yeah, I would ... If it was the one in front of my house, yeah! I'd probably go out every day. (respondent no. 01.01.03.2)

I'd like to think it's all of our responsibilities, but I know that's a little bit starry-eyed. (respondent no. 11.01.06-2)

A principal concern for many people was that they should not have to pay more in labour or money for Suds maintenance; in the UK it was felt that council tax should cover such provisions, whereas in Portland, water bills were felt to be high enough already.
We would hope that ... Council Tax pays for that. We would not expect to pay on top of that, and people would not expect to be doing voluntary stuff on top of that. (respondent no. 11.01.03.2) Not on my water bill! My water bill's huge already! But they do come and maintain them, so we are paying for them somehow ... But I don't want more money on my water bill! (respondent no. 01.01.02.2)

Willingness to pay for or contribute to maintenance will be affected by perceptions of the benefits of Suds systems. This will be related directly to awareness of risk potentialities in both people's own, and neighbouring, communities.

\subsection{Risk perception}

In Bristol, residents the authors spoke to were confident that the area would not flood.

I've lived here for 15 years and I've never had a flood, and my insurance isn't affected by it. It's not a flood-risk area, so that's all good in my books. (respondent no. 11.01.03.2)

As far as I know, flooding has never been a problem here; I looked into the flood risk before we bought the property. It suggested that, though we are in the zone, it's very slim. It's telling you that it could flood, for the sake of covering themselves, rather than actually being a possibility in our time here. (respondent no. 11.01.04.2)

Similarly in Portland, the possibility of flooding was often not accepted because of the slight incline of the road.

We are really right at the top of an incline, so when it rains it flows right down. (respondent no. 01.01.06.2)

We're in the heights here. I've lived here 30 years and we've never had any problem with flooding. So no, I really don't think about it that much. (respondent no. 01.01.07.12)

This again speaks to the need for better communication between the city and residents as to the rationale behind bioswale placement. For bioswales placed on inclines to reduce flooding at the lower end, those residents with the bioswales nearest to them are not always the ones at most risk. Some people felt that Suds should be placed principally at the water's end-point.

Past __ a little bit down, that's where it's worst. They need to put more down there. When it rains it puddles right out to the middle of the street. (respondent no. 01.01.03.1)

Questions about drought were often met with humour - disregarding that anywhere with 'so much rain' could ever have serious problems.

For drought, it's much the same as anywhere really. You can do your water-butt and save water, but it doesn't feel like a big issue in Britain! It'll rain again in a week or two ... it's not the end of the 
world, and if my little lawn dies, it'll grow back next year. I'm really not worried about it. (respondent no. 11.01.03.2)

I'm more aware of the flooding, for sure. Probably not that much more about drought, because that hasn't been an issue here in the last 10 years. (respondent no. 01.01.08.2)

With Portland, a couple of respondents were aware of the city's dependence upon the Mount Hood snowpack for part of their water supply. Overall, however, awareness of both flood and drought risk seemed to be dependent upon a heuristic risk evaluation, whereby recent experience and partial knowledge is substituted for 'official' and scientific estimates (Tversky and Kahneman, 1974).

\section{Discussion}

The findings from this research serve to confirm the findings of Apostolaki and Jefferies (2005) and Bastien et al. (2011) that awareness and understanding of Suds' water functions (and indeed their existence) can be low. Education, consultation and clear communication between water management groups and residents are important for raising both awareness and satisfaction, and the quotes in Section 3.3 show that a number of residents were keen for this to happen. Both bioswales and permeable paving were for the most part appreciated for aesthetic or environmental reasons; when water functions were explained, appreciation markedly improved for some respondents. From this small sample, improvement in perceptions of the Suds over time since installation was not observed and, for a few people, opinions actually worsened due to the behaviour of others (such as littering and the mishandling of the permeable paving). The opinions of those who appreciated them improved upon learning about water functions; the opinions of those who did not appreciate them in the first place did not appear to alter. The question remains, if water functions had been explained from pre-installation, whether impressions may have improved over time.

\section{Conclusion}

This study has built upon others' findings to investigate public awareness, understanding and preferences around two different Suds systems. The study's main findings point to a lack of awareness and understanding of Suds function at both sites.

In the cases studied, more consultation with residents could have helped to develop greater consensus around the approaches adopted, an understanding of the Suds' operation and an awareness of appropriate behaviour to encourage optimal functioning. Tailoring Suds to community needs could increase the perceived benefits and so willingness to be involved with maintenance; lay maintenance could reduce installation life-cycle costs. Pre- and post-installation engagement could therefore reduce overall costs and help to ensure longer-term functionality. Results suggest that continuing education would be needed to maintain community knowledge, as house occupation changes over time; designing facilities to show their function more clearly and with clearer site information could help to reduce these education costs.

More research is needed to continue deepening the understandings outlined here, working with different sectors of the public and types of Suds. The paper's findings would appear to be widely transferrable, but further research may highlight other considerations. Because of the small sample size, observations noted here should not be interpreted as overarching generalisations, but rather as time- and place-limited findings from two specific case studies.

\section{Acknowledgements}

This research was performed as part of an interdisciplinary project programme 'Clean water for all', undertaken by the Blue-Green Cities Research Consortium (www.bluegreencities. ac.uk) and the Portland-Vancouver urban long-term research area (Ultra) project. The consortium is funded by the UK Engineering and Physical Sciences Research Council under grant EP/K013661/1, with additional contributions from the Environment Agency and Rivers Agency (Northern Ireland). Ultra is funded by the United States National Science Foundation under grant 0948983.

\section{REFERENCES}

Achleitner S, Engelhard C, Stegner U and Rauch W (2007) Local infiltration devices at parking sites - experimental assessment of temporal changes in hydraulic and contaminant removal capacity. Water Science and Technology 55(4): 193-200.

Apostolaki S and Jefferies C (2005) Social Impacts of Stormwater Management Techniques Including River Management and SUDS. Environment Agency, Bristol, UK, Final report SUDS01.

Barr S, Gilg A and Shaw G (2011) Citizens, consumers and sustainability: re(framing) environmental practice in an age of climate change. Global Environmental Change 21(4): 1224-1233.

Bastien NRP, Arthur S and McLoughlin MJ (2011) Valuing amenity: public perceptions of sustainable drainage systems ponds. Water and Environment Journal 26(1): $19-29$.

BES (2005) Portland Watershed Management Plan: Annual Report. Bureau of Environmental Services, Portland, USA.

BES (2007) Green Streets Resolution. Bureau of Environmental Services, Portland, OR, USA. See https://www. portlandoregon.gov/bes/article/154232 (accessed 20 May 2014).

BES (2014) City of Portland 2014 Stormwater Management Manual. Bureau of Environmental Services, Portland, USA.

Bryant A and Charmaz K (2010) The SAGE Handbook of Grounded Theory. Sage, London, UK. 
Davis AP, Shokouhian M, Sharma H and Minami C (2001) Laboratory study of biological retention for urban stormwater management. Water Environment Research 73(1): $5-14$

Defra (2005) Making Space for Water: Taking Forward a New Government Strategy for Flood and Coastal Erosion Risk Management in England. Department for the Environment, Food and Rural Affairs, London, UK.

Dingman SL (2008) Physical Hydrology. Waveland Press, Illinois, USA.

EPA (2007) Reducing Stormwater Costs Through Low Impact Development (Lid) Strategies and Practices. United States Environmental Protection Agency, Washington D.C., USA.

EPA (2013) Stormwater to Street Trees: Engineering Urban Forests for Stormwater Management. United States Environmental Protection Agency, Washington DC, USA.

Getter KL, Rowe DB and Andresen JA (2007) Quantifying the effect of slope on extensive green roof stormwater retention. Ecological Engineering 31(4): 225-231.

Glaser BG and Strauss AL (2009) The Discovery of Grounded Theory: Strategies for Qualitative Research. Transaction Publishers, London, UK.

Hargreaves T (2010) Putting Foucault to Work on the Environment: Exploring Pro-environmental Behaviour Change as a Form of Discipline. Centre for Social and Economic Research on the Global Environment (CSERGE), School of Environmental Sciences, University of East Anglia, Norwich, CSERGE working paper, EDM, No. $10-11$.

Heal KV (2000) SUDS ponds in Scotland - performance outcomes to date. In Twentieth Meeting of the Standing Conference on Stormwater Source Control, 19 September 2000 (Pratt CJ (ed.)). School of the Built Environment, Covtd University, Coventry, UK.

Heal KV, Bray R, Willingale SAJ et al. (2008) Medium-term performance and maintenance of SUDS: a case study of Hopwood Park Motorway Service Area, UK. Proceedings of the 11th International Conference on Urban Drainage, Edinburgh, Scotland, UK.

Johnson CL and Priest SJ (2008) Flood risk management in England: A changing landscape of risk responsibility. International Journal of Water Resources Development 24(4): 513-525.

Jones P and Macdonald N (2007) Making space for unruly water: sustainable drainage systems and the disciplining of surface runoff. Geoforum 38(3): 534-544.

Kenyon W (2007) Evaluating flood risk management options in Scotland: A participant-led multi-criteria approach. Ecological Economics 64(1): 70-81.
Kurtz T (2010) Ecoroof performance monitoring in Portland, Oregon. Proceedings of International Low Impact Development Conference - Redefining Water in the City. American Society of Civil Engineers, San Francisco CA, USA.

Land and Water Constructions (2006) Review of Street Scale WSUD in Melbourne, Melbourne, Australia. Kingston City Council, Melbourne, Australia.

McKissock G, Jefferies C and D'Arcy BJ (1999) An assessment of drainage best management practices in Scotland. Water and Environment Journal 13(1): 47-51.

Mitchell G (2005) Mapping hazard from urban non-point pollution: a screening model to support sustainable urban drainage planning. Journal of Environmental Management 74(1): 1-9.

Netusil NR, Levin Z, Shandas V and Hart T (2014) Valuing green infrastructure in Portland, Oregon. Landscape and Urban Planning 124: 14-21. See http://www.sciencedirect.com/ science/article/pii/S0169204614000036 (accessed 29/05/ 2014).

Peters NE (1994) Hydrologic processes. In Biogeochemistry for Small Catchments: A Tool for Environmental Research (Moldan B and Cerny J (eds)). Wiley, Chichester, UK, Scientific Committee on Problems of the Environment (Scope), Scope 51.

Pitt M (2008) The Pitt Review - Learning Lessons from the 2007 Floods: An Independent Review. Cabinet Office, London, UK.

Proshansky HM, Fabian AK and Kaminoff R (1983) Place-identity: physical world socialization of the self. Journal of Environmental Psychology 3(1): 57-83.

Reinhardt G (2011) Portland advances green stormwater management practices. In Cities Going Green: A Handbook of Best Practices (Kemp RL and Stephani CJ (eds)). Shutterstock, Jefferson, North Carolina, USA.

Scottish Government (2003) The Water Environment and Water Services (Scotland) Act 2003 (Commencement No. 8) Order 2008. The Scottish Government, Edinburgh, UK, Scottish Statutory Instrument 2008 No. 269 (C. 22).

Shandas V, Nelson A, Arendes C and Cibor C (2010) Tabor to the River: An Evaluation of Outreach Efforts and Opportunities for Engaging Residents in Stormwater Management. Technical Report. City of Portland Bureau of Environmental Services, Portland, Oregon, USA.

Tversky A and Kahneman D (1974) Judgment under uncertainty: Heuristics and biases. Science 185(4157): $1124-1131$

Wengraf T (2001) Qualitative Research Interviewing: Biographic Narrative and Semi-Structured Methods. Sage, London, UK.

Werritty A, Houston D, Ball T, Tavendale A and Black A (2007) Exploring the Social Impacts of Flood Risk 
and Flooding in Scotland. Scottish Executive, Edinburgh.

World Bank (2014) Data: Urban Population (\% of Total). See http://data.worldbank.org/indicator/SP.URB.TOTL. IN.ZS (accessed 20/04/2014).
Zhou Q, Panduro TE, Thorsen BJ and Arnbjerg-Nielsen K (2013) Adaption to extreme rainfall with open urban drainage system: an integrated hydrological cost-benefit analysis. Environmental Management 51(3): $586-601$.

\section{WHAT DO YOU THINK?}

To discuss this paper, please email up to 500 words to the editor at journals@ice.org.uk. Your contribution will be forwarded to the author(s) for a reply and, if considered appropriate by the editorial panel, will be published as discussion in a future issue of the journal.

Proceedings journals rely entirely on contributions sent in by civil engineering professionals, academics and students. Papers should be 2000-5000 words long (briefing papers should be 1000-2000 words long), with adequate illustrations and references. You can submit your paper online via www.icevirtuallibrary.com/content/journals, where you will also find detailed author guidelines. 